\title{
THE AGRICULTURE AND FOOD: DOES IMPORT SUBSTITUTION TAKE PLACE? ${ }^{1}$
}

\author{
N.Shagaida, V.Uzun
}

The situation in the agriculture and with food supplies can be characterized by a number of trends:

- there is high food inflation in Russia for the fourth time in the past ten years; its level does not exceed so far the indices of 2007, 2008 and 2010;

- reduction of households' real income resulted in a decrease in demand on food; stable trend of reduction of retail trade physical volumes is observed;

- the agriculture has reacted to changes in the market situation: output volumes of both export-orientated production (grain and oil-yielding crop) and import-substituted products (sugar beet instead of sugar-cane), as well as supplies of buckwheat, potatoes and vegetables have increased; However, from April 2015 growth rates of the agriculture happened to be below the 2014 level;

- reduction of the volumes of the import of food in foreign currency did not result in reduction of its ruble equivalent as a whole. The above factor is indirect evidence of the fact that households keep spending a similar amount of funds as in the previous year on purchasing of a smaller quantity of import products. However, as regards dairy products, there is a reduction of the import both in volumes and in monetary (foreign currency and ruble) terms which situation could create conditions for import substitution. Below, the nuances of that process are considered.

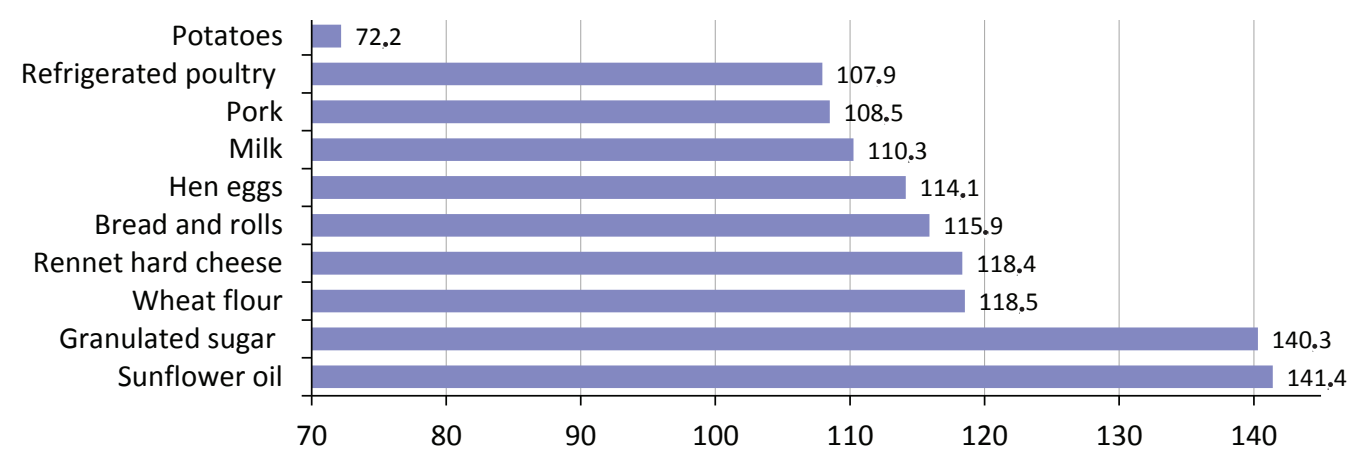

Source: The Rosstat.

Fig. 1. Weekly chain index of prices on the main food products (4 August $2014-5$ October 2015), \%

Introduction of the countersanctions from 8 August 2014 and depreciation of the exchange rate of the ruble affected significantly food prices. Generally, in the entire period from the introduction of the countersanctions the main food products appreciated by 8-40\% (Fig. 1) ${ }^{1}$.

From December 2014 till August 2015, the food inflation amounted to $9.8 \%$. High food inflation was observed four times in the past decade. As seen from the past experience, slowdown and even reduction of its growth rates does not exclude growth in the inflation rate before the end of the year (Fig. 2).

Prices were under pressure on the part of consumers whose demand on food was falling. Generally, in

1 Article form the online monitoring of the economic situation in Russia. Trends and Challenges of the Social and Economic Development. 2015. No.14. October.

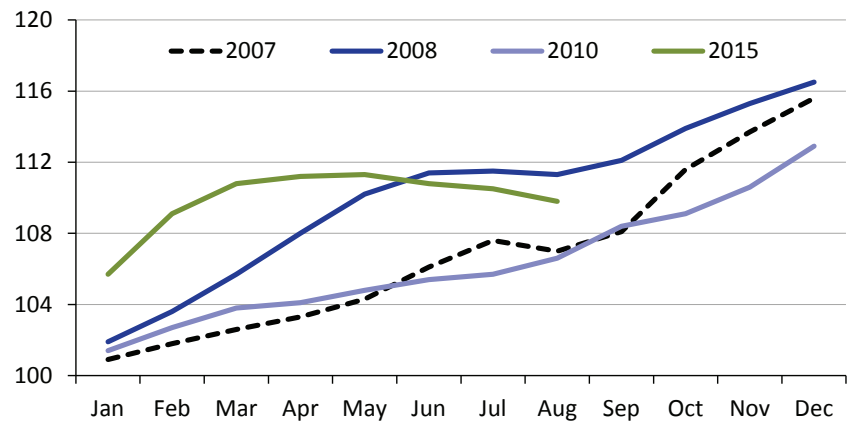

Source: The Rosstat.

Fig. 2. The index of prices on food as compared to December 2014

January-August households' read disposable cash income fell by about 3\%, while in August, by $5 \%$ as compared to the previous year (Table 1). 
Table 1

DYNAMICS OF DISPOSABLE CASH INCOME, \% AS COMPARED TO THE RESPECTIVE PERIOD OF THE PREVIOUS YEAR

\begin{tabular}{|l|c|c|}
\hline & 2014 & 2015 \\
\hline January & 99 & 99.3 \\
\hline February & 99.1 & 98.4 \\
\hline March & 92.9 & 98.4 \\
\hline April & 100.5 & 96.1 \\
\hline May & 106.2 & 93.6 \\
\hline June & 96.6 & 96.5 \\
\hline July & 102.6 & 98 \\
\hline August & 104 & 95.1 \\
\hline January-August & 100.2 & 96.9 \\
\hline
\end{tabular}

Source: The Rosstat.

A $5 \%$ reduction of households' real disposable cash income changed households' demand on food: the index of retail trade physical volumes of food kept falling in 2015 and amounted by August to $90 \%$ as compared the level of 2014.

A segment of the group of regions with maximum changes in the retail trade volumes in comparable prices is shown in Table 2.

Changes in the index of monthly retail trade volumes in comparable prices are shown in Fig.3. A sustained downward trend is explicit. The worst indices in August were observed in the Republic of Crimea: food turnover fell to $66 \%$ as compared to August 2014.

In a situation of growing prices, replacement of import goods by domestic ones was observed in consumption. Growth in output of agricultural products and, partially, food industry products, a decrease in import and depreciation of the ruble contributed to that.

Agriculture. Though output growth in agriculture was observed, as was stated in the previous reviews starting from April 2015 its growth rates lagged behind those of the previous year (Fig. 4).

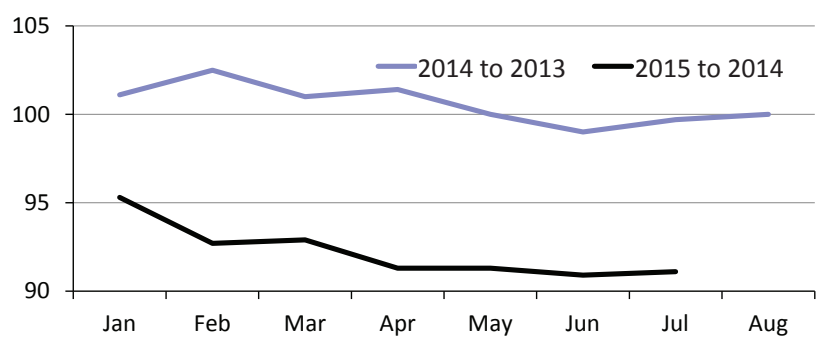

Source: The Rosstat

Fig. 3. The index of retail trade in food, including spirits and tobacco products,

$\%$ of the respective month of the previous year

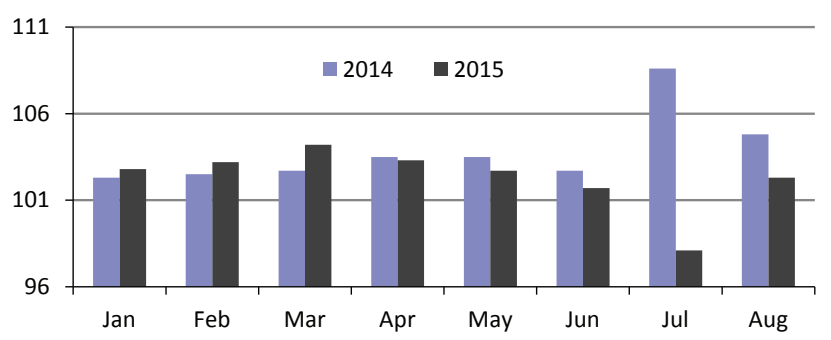

Source: The Rosstat.

Fig. 4. Dynamics of agricultural output, $\%$ of the respective period of the previous year

The best indices were registered in hog breeding ( $+13 \%$ as compared to August 2014) and poultry production (poultry meat: $+7 \%$, eggs: $+1 \%$ ). Production of milk remains at the same level despite growth in performance indices of agricultural entities ${ }^{1}$ (2.3\%). Evidently, termination of work with households' husbandries in such lines as support of dairy cattle husbandry and lending resulted in a situation where households' husbandries refused to engage in livestock management. It is hardly a correct decision as on the one side they called for the minimum support to be rendered by the state, while on the other side agri-

1 As in case of peasant farms if one takes into account the annual statistics. The data on the output of milk at peasant (private) farms is not provided monthly or quarterly.

\section{CHANGES IN THE RETAIL TRADE VOLUMES OF FOOD, INCLUDING BEVERAGES AND TOBACCO PRODUCTS} IN SOME RUSSIA'S REGIONS, JANUARY-AUGUST 2015/2014 IN COMPARABLE PRICES, \%

\begin{tabular}{|l|c|l|c|}
\hline \multicolumn{1}{|c|}{ Regions with better indices } & 2015/2014 & \multicolumn{1}{c|}{ Regions with worse indices } & $2015 / 2014$ \\
\hline Republic of Ingushetia & 141.7 & Penza Region & 85.2 \\
\hline Republic of Buryatia & 109.9 & Stavropol Territory & 84.3 \\
\hline Republic of Dagestan & 105.6 & Ivanovo Region & 83.9 \\
\hline Chukot Autonomous Region & 104.0 & Republic of Bashkortostan & 83.7 \\
\hline Republic of Tyva & 102.6 & Republic of Adygeya & 83.6 \\
\hline Maritime Territory & 102.4 & Belgorod Region & 83.4 \\
\hline Republic of Sakha (Jakutia) & 101.9 & Republic of Kalmykia & 82.9 \\
\hline Khabarovsk Territory & 101.1 & Samara Region & 80.9 \\
\hline Republic of Kabardino-Balkaria & 101.0 & Omsk Region & 78.6 \\
\hline Chechen Republic & 100.9 & Republic of Mari El & 77.1 \\
\hline
\end{tabular}

Source: The Rosstat. 
cultural entities (recipients of the main support) and farmers are not able to compensate the drop in milk production at households' husbandries.

The harvesting campaign is being carried out and a good yield of grain has been received. It is clear that producers react to demand and prices: output of buckwheat, potatoes, vegetables, sugar beet and other has increased. All those factors create conditions for potential import substitution. However, it is impossible to say that that process has been launched.

There is difference between commodity import substitution and monetary import substitution. The commodity import substitution is replacement of import products in kind $(\mathrm{kg}, \mathrm{l})$ with domestic products of similar quality. No commodity import substitution takes place, if import falls with a simultaneous reduction of consumption of that type of produce (including Russian one) by the same or higher value.

Monetary import substitution is a reduction of costs of the Russian consumer on purchasing of import food with growth in costs on Russian products and without taking into account changes in volumes. If the ruble was stable, it would be easier to solve the issue of import substitution. With depreciation of the ruble exchange rate, import substitution in physical terms may take place, but the monetary one does not: households may spend more on the same and even smaller volume of products. The Rosstat provides on a quarterly basis the data on the share of households' expenditures on import food in the total volume of spendings. The latest information was provided for Q1 2015 (Table 3).

Table 3

THE SHARE OF IMPORT FOOD (INCLUDING TOBACCO AND ALCOHOL PRODUCTS), \%

\begin{tabular}{|c|c|c|c|}
\hline Quarter & 2013 & 2014 & 2015 \\
\hline I & 36 & 36 & 32 \\
\hline II & 35 & 33 & \\
\hline III & 35 & 32 & \\
\hline IV & 36 & 36 & \\
\hline
\end{tabular}

Source: The Rosstat.
In accordance with the data shown in Table 3, there is monetary import substitution. However, that share may be underestimated as import primary products required for production of Russian goods are not taken into account. At the same time, that share may be overestimated as the pattern of import and Russian produce is calculated on the basis of retail prices with all the premiums prevailing in Russia included.

The cost of import products in Russian shops differs greatly upward from that declared on the border. Without going into technical details, in evaluation of the extent of the required substitution it is expedient to rely on the cost of import products declared on the border. That will permit to take into account the entire import and not only the import of ultimate products in the retail trade. Also, such a measure will exclude a portion of the cost of ultimate import products which is the result of premiums in Russia on the part of suppliers of those products to shops and shops themselves - over the price paid to a foreign provider or producer.

As import products are replaced, "premiums" to the price declared on the border will disappear. If the volume of the monetary import substitution is estimated that way, at present the substitution -- that is, refusal to pay to foreign producers - is estimated at $\mathrm{Rb}$ $352 \mathrm{bn}-372 \mathrm{bn}$ a quarter or about $11 \%$ of the cost of the consumed food in the country (two quarters of 2015) (Table 4).

The import of food in foreign currency fell to its minimum in February 2015 (56.7\% of the level of 2014), after that faltering growth continued: in July it amounted to $63.2 \%$ of the level of July 2014 (Fig. 5).

As compared to August, in the ruble equivalent the import exceeded the level of 2014 which situation is indirect evidence of the fact that households keep spending the same volume of funds on import products by reducing their quantity (Fig. 6). So, in monetary terms there is no import substitution.

Table 4

THE SHARE OF IMPORT FOOD IN RETAIL TRADE

\begin{tabular}{|c|c|c|c|c|c|c|c|c|c|}
\hline \multirow[t]{2}{*}{ 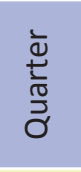 } & \multicolumn{3}{|c|}{$\begin{array}{l}\text { Volumes of retail trade in food } \\
\text { products (including bever- } \\
\text { ages and tobacco), billion } \mathrm{Rb}\end{array}$} & \multicolumn{3}{|c|}{$\begin{array}{l}\text { Import (Harmonized System } \\
\text { Codes of Foreign Economic } \\
\text { Activities 1-24), billion Rb. }\end{array}$} & \multicolumn{3}{|c|}{$\begin{array}{l}\text { The share of import food prod- } \\
\text { ucts in retail trade, \% (on the } \\
\text { basis of border prices) }\end{array}$} \\
\hline & 2013 & 2014 & 2015 & 2013 & 2014 & 2015 & 2013 & 2014 & 2015 \\
\hline 1 & 2481.6 & 2729.5 & 3098.1 & 301.4 & 354.6 & 372.4 & 12.1 & 13.0 & 12.0 \\
\hline II & 2691.0 & 2966.3 & 3252.2 & 336.4 & 362.8 & 352.2 & 12.5 & 12.2 & 10.8 \\
\hline III & 2818.3 & 3140.1 & 0.0 & 318.2 & 339.2 & 0.0 & 11.3 & 10.8 & 0.0 \\
\hline IV & 3152.1 & 3544.9 & 0.0 & 422.9 & 470.4 & 0.0 & 13.4 & 13.3 & 0.0 \\
\hline $\begin{array}{l}\text { For a } \\
\text { year* }\end{array}$ & 11143.0 & 12380.8 & 6350.3 & 1378.8 & 1527.0 & 724.6 & 12.4 & 12.3 & 11.4 \\
\hline
\end{tabular}

* as regards 2015, the data on $\mathrm{H} 1$ is available.

Source: The Rosstat and the Federal Customs Service. 


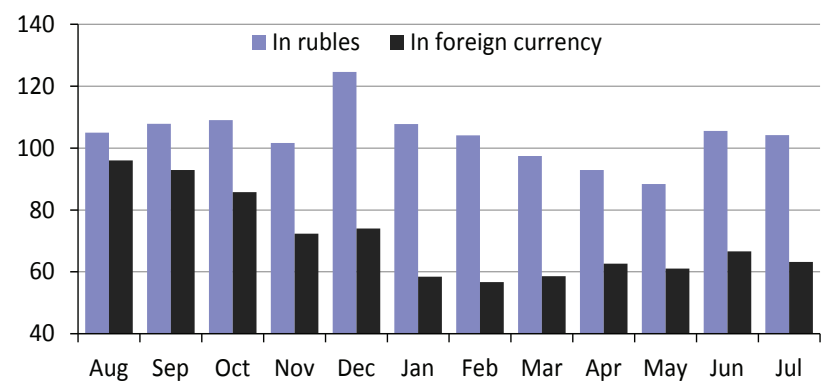

Source: The Federal Customs Service.

Fig. 5. Import of agricultural primary products and food (Harmonized System Codes of Foreign Economic Activities 1-24), 2014-2015 / 2013-2014, \%

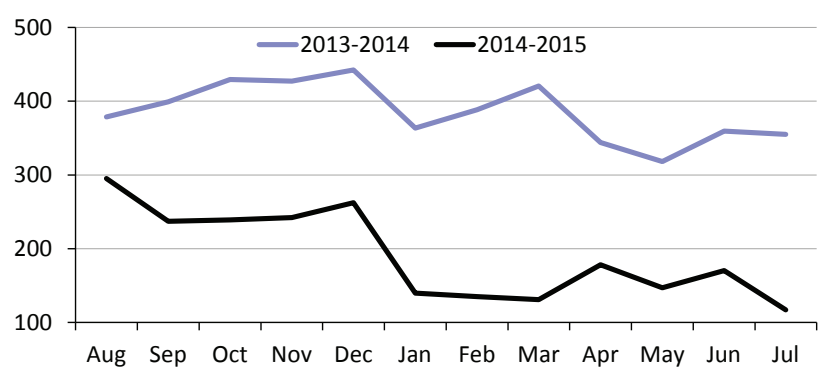

Source: The Federal Customs Service.

Fig. 7. Dynamics of the import of milk and dairy products, million USD

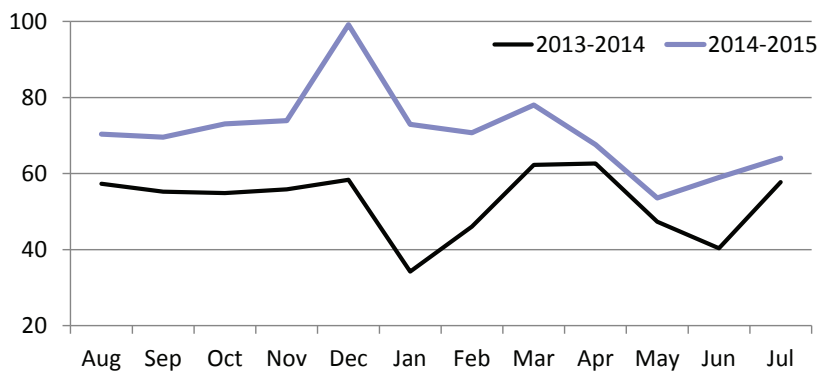

Source: The Federal Customs Service.

Fig. 9. Export of food and agricultural products from Russia by month (Harmonized System Codes of Foreign Economic Activities 1-24), billion Rb

Unlike import in general (including meat products), the import of dairy products fell both in USD terms (over 50\%) and ruble terms (Fig. 7 and 8 ).

It can be stated that the consumer has started to spend a smaller portion of its budget on import dairy products than in the previous year. However, one can speak about import substitution with great caution ${ }^{1}$.

1 The level of Russia's food independence as regards milk amounts to about $78 \%$, growth in milk production in the agriculture in Q1 2015 was equal to $+0.9 \%$ as compared to 2014 , while in Q2, to $-0.9 \%$; the import decreased by nearly $50 \%$. It means that there was a decrease in consumption, primarily, due to purchasing of import products.

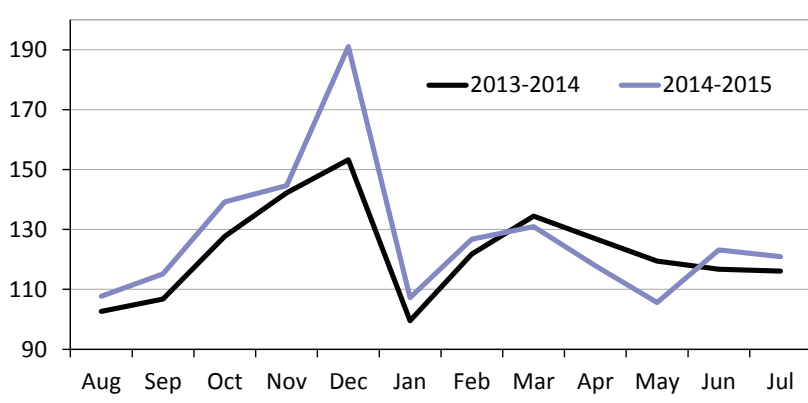

Source: The Federal Customs Service.

Fig. 6. The dynamics of import in August-July (Harmonized System Codes of Foreign Economic Activities 1-24), billion Rb

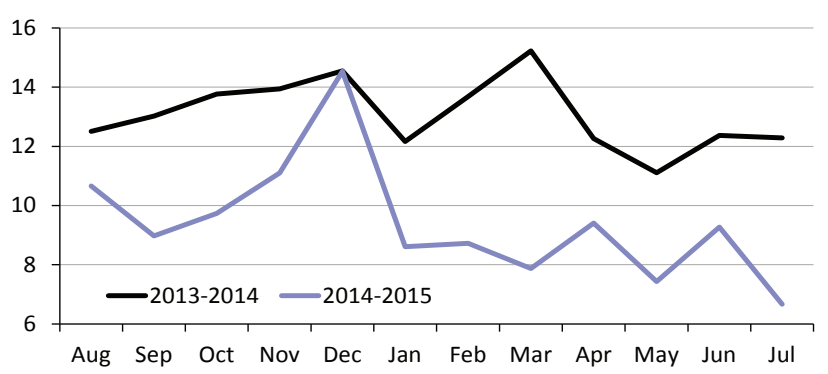

Source: The Federal Customs Service.

Fig. 8. The dynamics of import of milk and dairy products, billion $R b$ (the data as of 21 September 2015)

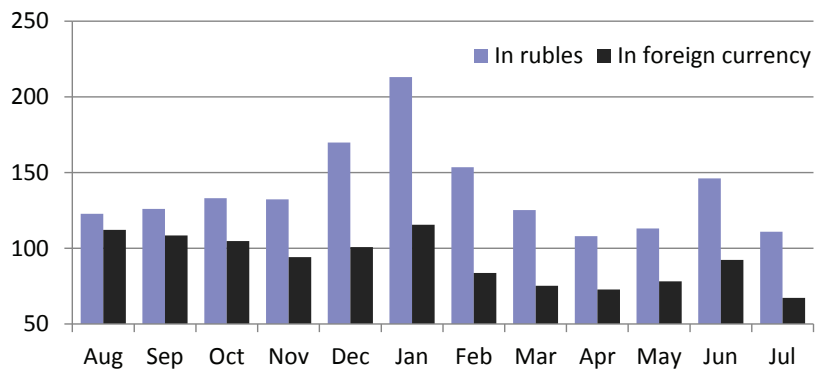

Fig. 10. Export of agricultural products and food by month in 2014-2015 as compared to 2013-2014 (Harmonized System Codes of Foreign Economic Activities 1-24), \% (the data as of 12.10.15)

From February 2015, the export of food in foreign currency fell to the level of 2014 which situation was contributed to by introduction of duties on grain - the main export product (Fig. 9).

It is to be noted that due to depreciation of the ruble exchange rate export operations remained attractive in the ruble equivalent: exporters' revenues exceeded the indices of the previous year by $8-54 \%$ (Fig. 9 and Fig. 10). 